\title{
Feenberg between instrumentalism and substantivism: formal principles versus humanistic values in democratic technical politics
}

\author{
Graeme Kirkpatrick \\ Professor in Media Arts, Aesthetics \& Narration, University of Skövde, Sweden \\ Box 408
}

\section{Skövde}

\section{Sweden}

Tel: +46 (0) 500448881

Accepted:

Feenberg's conception of technical politics emphasizes the contingency of technical designs on contemporary choices. The resulting technology facilitates more choices in future, broadening the horizon on our possible interactions with the world. Thus far, Feenberg allies his position with optimistic instrumentalism, preserving critical theory from alliance with anti-technology positions. At the same time, however, Feenberg maintains that past technical decisions shape our current context and this involves the sedimentation of values associated with technology in the cultural foundations of social life. This means Feenberg's technical politics requires a democratic framework to promote decisions aimed at producing better outcomes in the proximal, instrumental sense, but also needs reforms aimed at promoting more humanistic values through technology design. The first is would be consistent with the establishment of formal procedures aimed at the democratization of technology design but the second is more problematic, raising the question of what the humanistic values in question are.

Feenberg $(1999 ; 2002 ; 2010)$ delegates this issue to the aesthetic critique of technology design but this assumes inherent affinities between political, ethical and aesthetic values that may not hold. Feenberg's suggestion is that various forms of modernism, in which the natural and the technical are blended in the creation of environments that work better for humans, rather than more efficient machines, should inspire a re-framing of design as a humanistic practice (and a practice of humanizing 
the world). In essence he maintains that the meaning of rationalizing the world, which is a fundamental part of technology's mission, needs to be broadened by the inclusion of aesthetic principles at the normative heart of technology. The paper interrogates the meaning of 'aesthetic critique' in this context and suggests that this dimension of critical theory of technology should not involve the search for a more 'positive' or humanistic technological enframing but should rather limit itself to clarifying the place of technology design in a more progressive constellation of human-naturesociety.

\section{References and Notes}

Feenberg, A. (1999) Questioning Technology London.

Feenberg, A. (2002) Transforming Technology Oxford

Feenberg, A. (2010) Between Reason and Experience: Essays in technology and modernity London.

(C) 2015 by the authors; licensee MDPI and ISIS. This abstract is distributed under the terms and conditions of the Creative Commons Attribution license. 